\title{
Transient Behavior in Biodegradation of 2, 4 Dichlorophenol: Is It a Starvation Effect?
}

\author{
Taghreed T. Al-Khalid and Muftah H. El-Naas
}

\begin{abstract}
Batch experiments were carried out to examine the biomass acclimatization during the aerobic biodegradation of 2,4 dichlorophenol $(2,4$ DCP) by Pseudomonas putida immobilized in polyvinyl alcohol (PVA) gel pellets in a bubble column bioreactor. The bacteria was acclimatized to 2, $4 \mathrm{DCP}$ with concentrations of up to $200 \mathrm{mg} / \mathrm{l}$, with and without the addition of glucose. After the acclimatization, experiments were carried out with initial 2, 4 DCP concentrations ranging from 25 to $100 \mathrm{mg} / \mathrm{l}$. In the course of the study, a phenomenon was noticed that can be related to the effect of carbon starvation on the biodegradation ability of the bacterial cells. This paper presents the results on this phenomenon. Starved cells showed higher growth and degradation rates.
\end{abstract}

Index Terms-Biodegradation, Phenol, 2, 4 dichlorophenol, acclimatization, adaptation, starvation.

\section{INTRODUCTION}

Chemical and petroleum industries generate a wide variety of highly toxic organic pollutants, which have led to cumulative hazardous effects on the environment. The effluents of these industries often contain aromatic organic compounds that are rather resistant to natural degradation and therefore persist in the environment. This makes them capable of long range transportation and bioaccumulation in human and animal tissue. Organic pollutants represent a potential group of chemicals that can be seriously hazardous to human health [1]-[3]. Many aromatic compounds show carcinogenic, teratogenic or mutagenic properties [4]. Non-biodegradable organic compounds must be pretreated into biodegradable or less toxic compounds.

Contamination of soil, surface water, and underground water by aromatic organic pollutants such as phenol and its derivatives has caused great concern worldwide. Phenolic compounds are among the most prevalent forms of chemical pollutants in the industrial wastewater, generated mainly from oil refineries, coal conversion plants, petrochemicals, polymeric resins, pharmaceuticals, smelting, and related metallurgical operations [5]-[7]. Phenols are well known for their high toxicity for human life, aquatic life and others [8]-[10]. They are considered to be among the most hazardous contaminants, and they are certainly the most difficult to remove [11]. They are not amenable to conventional treatment process and, in the presence of chlorine, can react with chlorine to produce chlorophenols,

Manuscript received July 3, 2013; revised September 6, 2013. This work was supported by the United Arab Emirates University as part of the PhD Scholarship Program.

The authors are with the Department of Chemical and Petroleum Engineering, UAE University, UAE (e-mail: tkhalid@ uaeu.ac.ae, muftah@ uaeu.ac.ae). which are carcinogenic and even more resistant to degradation than phenol itself [12], [13].

Due to these adverse health effects of phenols, the World Health Organization (WHO) has set a guideline of $1 \mu \mathrm{g} / \mathrm{l}$ to regulate the phenol concentration in drinking water [14]. The high-volume use of phenols in the United States and their potential toxicity has led the U.S. Environmental Protection Agency (US EPA) to define them as priority pollutants [15]. Most countries specify the maximum allowable concentration of phenols in the effluent streams to be less than $1 \mathrm{mg} / \mathrm{l}$ [16], [17]. The legislations in the UAE limit the total phenols in industrial water discharged to the marine environment to $0.1 \mathrm{mg} / 1$ [18].

Therefore, to save the soils and aqueous ecosystems, it has been mandatory worldwide for industries to treat their wastewater effluents before safe disposal to the environment. Biological treatment of phenols has been an increasingly important process in pollution control [2], [19], [20]. Moreover, compared with physico-chemical methods, the biodegradation method of phenols removal is a more environmental friendly and cost effective alternative, universally preferred, because of the possibility of complete mineralization of phenol [2], [11], which results in complete conversion of a compound to its inorganic mineral constituents [1]. It is considered a favorable and most promising approach [10].

Biomass immobilization is an important and effective technique that is usually employed to protect the bacteria from high phenol concentrations and allow reutilization of the biomass [11], [20], [21]. Many types of aerobic bacteria, including Pseudomonas putida, are believed to be capable of consuming aromatic compounds as the only source of carbon and energy [11], [20], [21]. In recent years, the strain of $P$. putida has been the most widely used type of bacteria for phenols biodegradation. It has been studied by many researchers in free and immobilized forms, using different types of bioreactors.

However, during biological treatment, the bacteria must first adapt to the phenolic compound, which is known to be toxic to microorganisms. It has been reported that phenols are inhibitory to bacteria growth at concentrations above $0.05 \mathrm{~g} / \mathrm{l}$ [21], [22]. Therefore, in order to obtain efficient biodegradation, microbial acclimatization to phenol or its derivatives is necessary [21].

The effect of lag times at the beginning of the process is specially recognized when the biomass cells are not pre-adapted to the contaminant medium. The lag time increases with increased initial concentration of phenol [23]. Microbial acclimatization (adaptation) to phenols is necessary [21], [23]. This process has often been carried out by involving a start with glucose as an easily biodegradable 
source of organic compounds [11]. Biomass activity and acclimatization process were examined by studying the effect of glucose presence on the biodegradation of 2,4 dichlorophenol (2, 4 DCP) using immobilized $P$. putida in a bubble column bioreactor. In the course of this study, a transient phenomenon was noticed involving a repression or decrease in the degradation rate when repeating an experiment before achieving a complete removal of the organic substrate from the previous run. In this work, results on this phenomenon are presented.

\section{Materials AND Methods}

Detailed description of the bacteria preparation, acclimatization and immobilization as well as the analytical techniques can be found elsewhere [11]. However, for the sake of clarity and completeness, brief descriptions are presented here.

\section{A. Reagents}

Analytical grade 2, 4 DCP was obtained from Sigma-Aldrich, Germany with purity greater than $99 \%$. Synthetic 2, 4 DCP solutions were prepared in the desired concentrations by dissolving predetermined amount of 2, 4 DCP in nutrient solution (Section D). The prepared solutions were always kept in dark containers in closed cabinets to avoid light oxidation of 2, 4 DCP. All other chemicals and polyvinyl alcohol (PVA) powder were of analytical grade and were obtained from BDH, UK.

\section{B. Preparation of Microbial Culture}

A special strain of the bacterium P. putida (P300) was obtained in an AMNITE cereal form from Cleveland Biotech Ltd., UK. A $100 \mathrm{~g}$ portion of the cereal was mixed in a 1000 $\mathrm{ml}$ of $0.22 \%$ sodium hexameta phosphate buffered with $\mathrm{Na}_{2} \mathrm{CO}_{3}$ to a $\mathrm{pH}$ of 8.5 . The mixture was homogenized in a blender for about one hour, decanted and kept in the refrigerator at $4^{\circ} \mathrm{C}$ for $24 \mathrm{~h}$. Bacteria slurry was prepared by four consecutive steps of low speed centrifugation at 6000 rpm for $15 \mathrm{~min}$. The supernatants were collected and centrifuged again at 10,000 rpm for $20 \mathrm{~min}$. The biomass attached to the walls of tubes was re-suspended in distilled water.

\section{Immobilization}

PVA gel was used for immobilizing the bacteria cells. A homogenous $10 \mathrm{wt} \%$ PVA viscous solution was prepared by mixing $100 \mathrm{~g}$ of PVA powder with $900 \mathrm{ml}$ of distilled water at about $70-80 \circ \mathrm{C}$. The $10 \%$ mixture is known to result in good quality polymer matrix with high porosity [11]. It is believed that PVA, which is a synthetic polymer, has better mechanical properties, and it is more durable than Ca-alginate which is biodegradable and can be subject to abrasion [11]. The formed mixture was allowed to cool to room temperature before adding $10 \mathrm{ml}$ of the bacterial suspension prepared as in Section 2.2, then well stirred for 10-15 minutes to ensure homogeneity of the solution. The solution was then poured into special molds and kept in a freezer at $-20{ }^{\circ} \mathrm{C}$ for $24 \mathrm{~h}$, then transferred to room temperature and allowed to thaw at about $4{ }^{\circ} \mathrm{C}$. The freezing-thawing process was repeated 4 times, with $5 \mathrm{~h}$ for each cycle. The frozen molds were cut into the specified sizes, washed with distilled water to remove any uncross-linked chains, and sent for acclimatization.

\section{Acclimatization of Bacteria}

A portion of $90 \mathrm{ml}$ of the immobilized bacteria, prepared as in Section $\mathrm{C}$, was suspended in a measuring cylinder, to a total volume of $300 \mathrm{ml}$ in solution containing $1000 \mathrm{mg} / \mathrm{l}$ of glucose as an easy biodegradable source of organic carbon in addition to $825 \mathrm{mg} / \mathrm{l}$ of other essential mineral nutrients with concentrations shown in Table I. Once activated, the bacteria were then slowly acclimatized to 2, 4 DCP concentrations by increasing the 2, 4 DCP concentration from zero to 50, 100, 150 , up to $200 \mathrm{mg} / \mathrm{l}$ over a period of 5 days. At the same time, glucose concentration was gradually reduced from $1000 \mathrm{mg} / \mathrm{l}$ to zero $(1000,750,500,250,0 \mathrm{ppm})$. Another portion of 90 $\mathrm{ml}$ of the immobilized bacteria was suspended to a total volume of $300 \mathrm{ml}$ nutrient solution containing $25 \mathrm{mg} / \mathrm{l}$ of 2, 4 DCP as a source of organic carbon dissolved in the nutrient solution. The bacteria were then slowly acclimatized to 2,4 DCP concentrations by increasing the 2, 4 DCP concentration from 25 to $50,100,150$, up to $200 \mathrm{mg} / \mathrm{l}$ over a period of 5 days.

In all runs, the portion having glucose in the acclimatization process is termed $\mathrm{A}$, while the no-glucose portion is termed $B$.

\section{E. Analytical Methods}

2, 4 DCP concentrations in the biomass-free samples were determined quantitatively using a Shimadzu UV Spectrophotometer, Model UV-1800, Japan at $243 \mathrm{~nm}$. Measurements were made after filtering the samples through $0.45 \mu \mathrm{m}$ GHP Acrodisc filter. Residual concentration was determined against a calibration curve of standard solutions of known concentrations and a standard solution was used to recheck the accuracy of the spectrophotometer every day. All experimental results reported in the study were based on averaging results of repeated experimental runs (duplicates or triplicates).

TABLE I: COMPOSITION OF NUTRIENT MINERAL MEDIUM

\begin{tabular}{lc}
\hline Component & Concentration, mg/l \\
\hline $\mathrm{MgSO}_{4} \cdot 7 \mathrm{H}_{2} \mathrm{O}$ & 300 \\
$\mathrm{~K}_{2} \mathrm{HPO}_{4}$ & 250 \\
$\mathrm{CaCl}_{2} \cdot 2 \mathrm{H}_{2} \mathrm{O}$ & 150 \\
$\left(\mathrm{NH}_{4}\right)_{2} \mathrm{CO}_{3}$ & 120 \\
$\mathrm{FeSO}_{4} \cdot 7 \mathrm{H}_{2} \mathrm{O}$ & 3.5 \\
$\mathrm{ZnSO}_{4} \cdot 7 \mathrm{H}_{2} \mathrm{O}$ & 1.3 \\
$\mathrm{MnCl}_{2} \cdot \mathrm{H}_{2} \mathrm{O}$ & 0.13 \\
$\mathrm{CuSO}_{4} \cdot 5 \mathrm{H}_{2} \mathrm{O}$ & 0.018 \\
$\mathrm{CoCl}_{2} \cdot 6 \mathrm{H}_{2} \mathrm{O}$ & 0.015 \\
$\mathrm{Na}_{2} \mathrm{MnO}_{4} \cdot 2 \mathrm{H}_{2} \mathrm{O}$ & 0.013
\end{tabular}

\section{F. Batch Biodegradation of 2, 4 DCP}

After acclimatization, and before stating the runs, the PVA gel cubes were soaked in the substrate solution of required 
concentration for 10 minutes, then the soaking solution was decanted and the fresh solution added. All biodegradation experiments using the culture were performed in $500 \mathrm{ml}$ measuring cylinder containing a total volume of $300 \mathrm{ml}$. The cylinder was initially filled with standard mineral medium, prepared according to Table I, which contained the required concentration of the substrate and 30 vol\% PVA gel cubes with immobilized bacteria. The cylinder was immersed in a water bath to control the temperature at $30{ }^{\circ} \mathrm{C}$. Air was continuously introduced into the reactor to enhance mixing and at the same time provide excess oxygen to sustain aerobic condition. Initial $\mathrm{pH}$ ranged from 8.1-8.5. Initial 2, 4 DCP concentration ranged from $25 \mathrm{mg} / 1$ to $100 \mathrm{mg} / 1$ and samples were withdrawn at regular time intervals, and analyzed for residual 2, 4 DCP concentration.

\section{RESUlTS AND DISCUSSION}

The results are shown for batch biodegradation of 2, 4 DCP with freshly prepared bacteria, directly acclimatized to 2, 4 DCP up to $200 \mathrm{mg} / \mathrm{l}$ as explained in Section D, for initial 2, 4 DCP concentrations of 25, 50, 75 and $100 \mathrm{mg} / \mathrm{l}$. The results for $25 \mathrm{mg} / \mathrm{l}$ are shown in Fig. 1. The phenomenon of repression in the degradation rate when running an experiment before achieving a previous complete removal of substrate is noticed, as depicted by Runs $1 \mathrm{~A}$ and $1 \mathrm{~B}$, which were carried out directly after the last step of acclimatization at $200 \mathrm{mg} / \mathrm{l}$ that ended with about $25 \mathrm{mg} / \mathrm{l}$ and did not reach zero concentration. For a concentration of $50 \mathrm{mg} / \mathrm{l}$, several runs were carried out as shown in Fig. 2 and Fig. 3 for bacterial portions A and B, respectively. A repeat of Run 1 (Run 1R) was performed on the same day of performing Run 1 , after about half an hour of terminating Run 1. The same procedure applies for Run $2 \mathrm{R}$. It is noteworthy to mention that: 1 . Repeating an experiment before achieving a complete removal of substrate slows the degradation rate, as depicted by Runs $1 \mathrm{R}$ and $2 \mathrm{R}$ in the Figs, which were performed on the same day of performing Runs 1 and 2, respectively. 2. The degradation rate was continuously improving upon repeating the experiment after complete degradation, as depicted by Runs 1, 2 and 3.

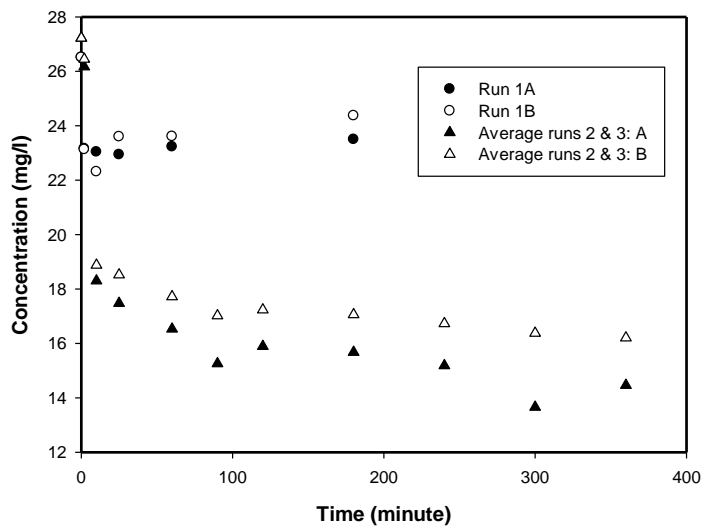

Fig. 1. Variation of 2, 4 DCP concentration, initial concentration $25 \mathrm{mg} / 1$

As for the initial concentration of $75 \mathrm{mg} / \mathrm{l}$, several runs were performed and the averages are shown in Fig. 4 (no runs were started before complete removal of 2, 4 DCP). The results for $100 \mathrm{mg} / \mathrm{l}$ are shown in Fig. 5. The same phenomenon of decrease in the degradation rate when repeating an experiment before achieving a complete removal of substrate applies also, as depicted by Runs AR and $\mathrm{BR}$ in the Fig, for bacterial portions $\mathrm{A}$ and $\mathrm{B}$, respectively.

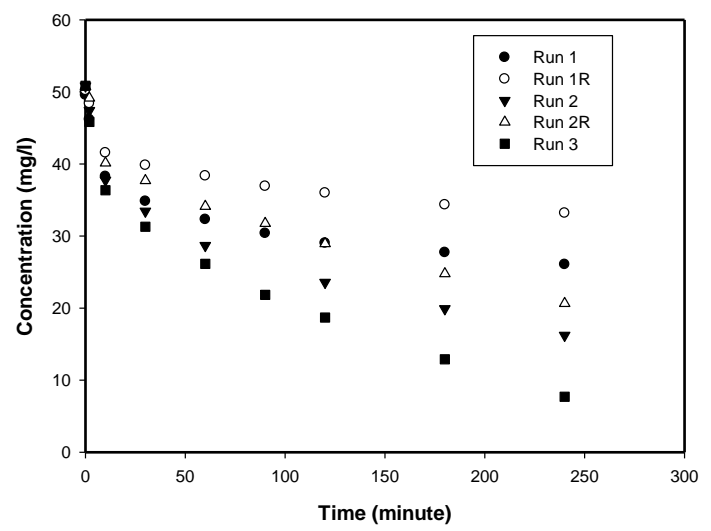

Fig. 2. Variation of 2, 4 DCP concentration with time, initial concentration $50 \mathrm{mg} / \mathrm{l}$ : bacteria A

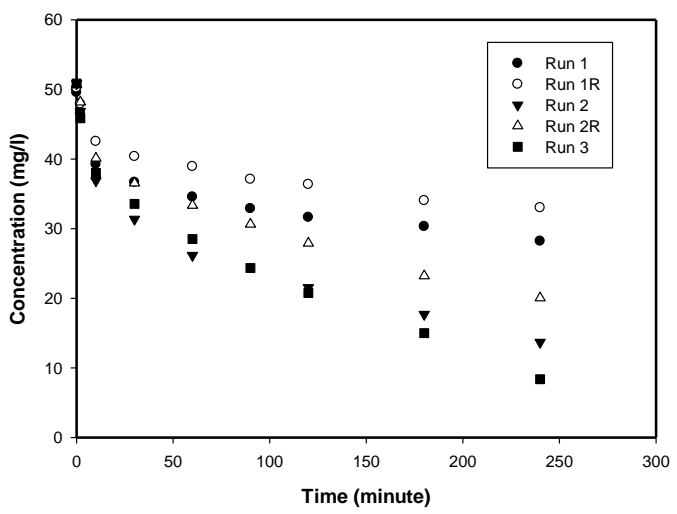

Fig. 3. Variation of 2, 4 DCP concentration with time, initial concentration $50 \mathrm{mg} / \mathrm{l}$ : bacteria B

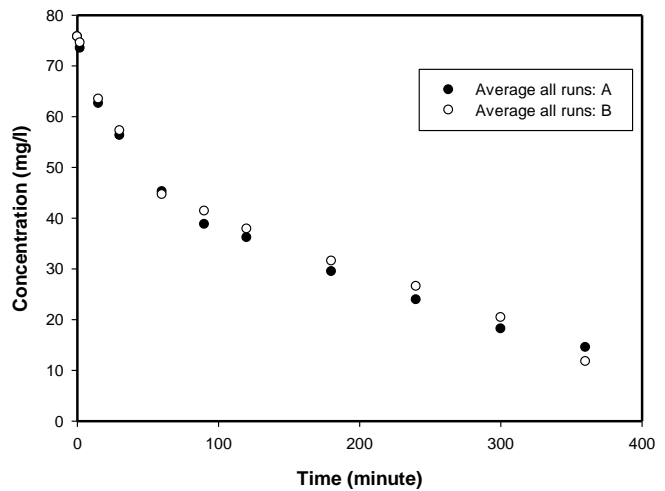

Fig. 4. Variation of 2, 4 DCP concentration , initial concentration $75 \mathrm{mg} / 1$

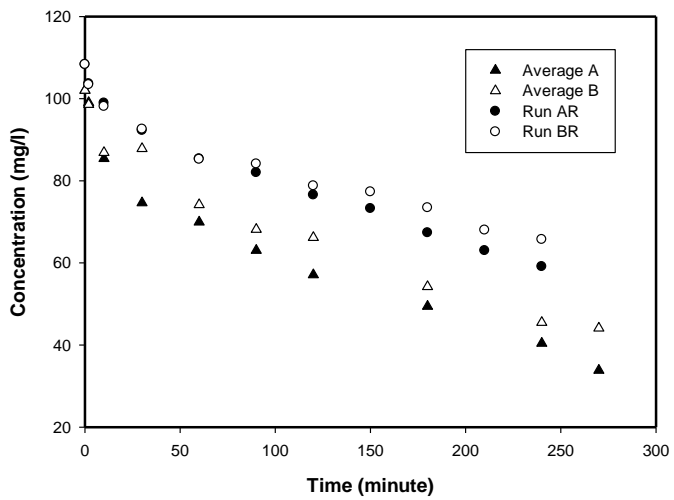

Fig. 5. Variation of 2, 4 DCP concentration with time, initial concentration $100 \mathrm{mg} / \mathrm{l}$ 
This phenomenon can be attributed to the effect of carbon starvation on cells growth and biodegradation capabilities. Shourian et al. [10] found that carbon starved cells had higher growth rate and higher biodegradation rate of phenol in comparison with non-starved cells in the exponential growth phase. They reported that the rate of phenol degradation is influenced by the energetic status or growth phase of the cells. The same findings were reported by Khleifat [15] for the degradation of phenol by Ewingella americana. According to the study, starvation increased the cells ability to utilize the organic substrate and the nutrients and decreased the lag time. Khleifat [15] explained that the quantity of the enzymes is the same but it is the time of early or late expression of catabolic genes that makes the difference. Additionally, a study by Varma and Gaikwad [24] for biodegradation of phenol by the yeast Candida tropicalis NCMI 3556 revealed that grown cells (already exiting the exponential phase) could degrade $100 \%$ of $2000 \mathrm{mg} / \mathrm{l}$ phenol whereas only $32 \%$ could be degraded when phenol was added to a medium with growing cells (still in the exponential phase). More elaborate studies should be directed to this issue.

\section{CONCLUSION}

The transient phenomenon of repression or reduction in the biodegradation rate of 2, 4 DCP by PVA-immobilized $P$. putida when starting the biological treatment before confirming the complete removal of the substrate from previous treatment can be explained in the context of the carbon starvation effect. This effect has been pointed out in several studies in the literature. Carbon starvation for a maximum of 24 hours significantly decreases the time required for induction and complete degradation of organic substrates.

\section{REFERENCES}

[1] C. I. Nair, K. Jayachandran, and S. Shashidhar, "Biodegradation of phenol," Afr. J. Biotechnol., vol. 7, pp. 4951-4958, 2008.

[2] Y. J. Liu, A. N. Zhang, and X. C. Wang, "Biodegradation of phenol by using free and immobilized cells of Acinetobacter sp. XA05 and Sphingomonas sp. FG03," Biochem. Eng. J., vol. 44, pp. 187-192, 2009.

[3] T. P. Chung, H. Y. Tseng, and R. S. Juang, "Mass transfer effect and intermediate detection for phenol degradation in immobilized Pseudomonas putida systems," Process Biochem., vol. 38, pp. 1497-1507, 2003.

[4] G. Zhao, L. Zhou, Y. Li, X. X. Liu, X. Ren, and X. L. Liu, "Enhancement of phenol degradation using immobilized microorganisms and organic modified montmorillonite in a two-phase partitioning bioreactor," J. Hazard. Mater., vol. 169, pp. 402-410, 2009.

[5] R. D. Kumar and K. Palanivelu, "Electrochemical treatment of industrial wastewater," J. Hazard. Mater., vol. 113, pp. 123-129, 2004

[6] A. Kumar, S. Kumar, and Su. Kumar, "Biodegradation kinetics of phenol and catechol using Pseudomonas putida MTCC 1194," Biochem. Eng. J., vol. 22, pp. 151-159, 2005.

[7] M. Edalatmanesh, M. Mehrvar, and R. Dhib, "Optimization of phenol degradation in a combined photochemical-biological wastewater treatment system," Chem. Eng. Res. Des., vol. 86, pp. 1243-1252, 2008.

[8] G. K. Agarwal and A. K. Ghoshal, "Packed bed dynamics during microbial treatment of wastewater: Modelling and simulation," Bioresour. Technol., vol. 99, pp. 3765-3773, 2008.

[9] I. Stoilova, A. Krastanov, V. Stanchev, D. Daniel, M. Gerginova, and Alexieva, "Biodegradation of high amounts of phenol, catechol, 2,
[10] M. Shourian, K. A. Noghabi, H. S. Zahiri, T. Bagheri, G. Karballaei, M. Mollaei, I. Rad, S. Ahadi, J. Raheb, and H. Abbasi, "Efficient phenol degradation by a newly characterized Pseudomonas sp. SA01 isolated from pharmaceutical wastewaters," Desalination, vol. 246, pp. 577-594, 2009.

[11] M. H. E. Naas, S. A. Muhtaseb, and S. Makhlouf, "Biodegradation of phenol by Pseudomonas putida immobilized in polyvinyl alcohol (PVA) gel," J. Hazard. Mater., vol. 164, pp. 720-25, 2009.

[12] I. D. Santos, J. C. Afonso, and A. J. B. Dutra, "Behavior of a $\mathrm{Ti}^{2} / \mathrm{RuO}_{2}$ anode in concentrated chloride medium for phenol and their chlorinated intermediates electrooxidation," Sep. Pur. Techol., vol. 76 , pp. 151-157, 2010.

[13] Y. Yavuz and A. S. Koparal, "Electrochemical oxidation of phenol in a parallel plate reactor using ruthenium mixed metal oxide electrode," $J$. Hazard. Mater., vol. B136, pp. 296-302, 2006.

[14] J. Yan, W. Jianping, B. Jing, W. Daoquan, and H. Zongding, "Phenol biodegradation by the yeast Candida tropicalis in the presence of m-cresol," Biochem. Eng. J., vol. 29, pp. 227-234, 2006.

[15] K. M. Khleifat, "Biodegradation of phenol by Ewingella americana effect of carbon starvation and some growth conditions," Process Biochem., vol. 41, pp. 2010-2016, 2006.

[16] H. Kusic, N. Koprivanac, and A. L. Bozic, "Treatment of chlorophenols in water matrix by UV/ferrioxalate system: Part I. Key process parameter evaluation by response surface methodology," Desalination, vol. 279, pp. 258-268, 2011.

[17] P. S. Bapat, P. R. Gogate, and A. B. Pandit, "Theoretical analysis of sonochemical degradation of phenol and its chloro-derivatives," Ultrason. Sonochem., vol. 15, pp. 564-570, 2008.

[18] M. A. Zarooni and W. Elshorbagy, "Characterization and assessment of Al Ruwais refinery wastewater," J. Hazard. Mater., vol. A136, pp. 398-405, 2006.

[19] Y. Wang, Y. Tian, B. Han, H. B. Zhaw, J. N. Bi, and B. L. Cai, "Biodegradation of phenol by free and immobilized Acinetobacter sp. strain PD12," J. Environ. Sci., vol. 19, pp. 222-225, 2007.

[20] M. E. Naas, S. A. Zuhair, and S. Makhlouf, "Batch degradation of phenol in a spouted bed bioreactor system," J. Ind. Eng. Chem., vol. 16, pp. 267-272, 2010

[21] M. E. Naas, S. A. Zuhair, and S. Makhlouf, "Continuous biodegradation of phenol in a Spouted Bed Bioreactor (SBBR)," Chem. Eng. J., vol. 160, pp. 565-570, 2008.

[22] M. Bajaj, C. Gallert, and, J. Winter, "Biodegradation of high phenol containing synthetic wastewater by an aerobic fixed bed reactor," Bioresour. Technol., vol. 99, pp. 8376-8381, 2008.

[23] T. A. Khalid and M. H. E. Naas, "Aerobic biodegradation of phenols: a comprehensive review," Crit. Rev. Env. Sci. Technol., vol. 42, pp. 1631-1690, 2012.

[24] R. J. Varma and B. G. Gaikwad, "Rapid and high biodegradation of phenols catalyzed by Candida tropicalis NCIM 3556 cells," Enzyme Microb. Technol., vol. 43, pp. 431-435, 2008.

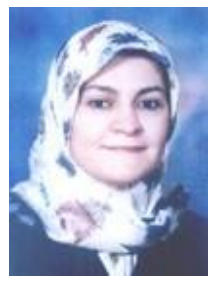

Taghreed T. Al-Khalid has B.Sc. in Chemical Engineering from Kuwait University (1982), and M.Sc. in Chemical Engineering from the University of Jordan (1996). From 1982 to 1990, she worked as a research associate at Kuwait Institute for Scientific Research From 1999 to 2010, she joined the UAE University as a teaching assistant and later as a research administrator. Currently, she is a $\mathrm{PhD}$ candidate in Chemical Engineering Department at the UAE University. Her research is in the area of biotechnology. T. Al-Khalid is a member of the Jordan Engineers Association.

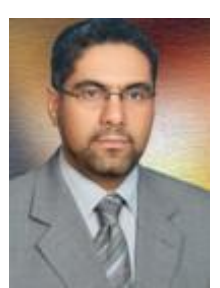

Muftah H. El-Naas is a professor and the chair of the Chemical and Petroleum Engineering Department at the UAE University. He obtained a B. A. Sc. in Chemical Engineering from the University of British Columbia, Canada, M. Eng. and PhD in Chemical Engineering from McGill University, Canada. His research interests include biotechnology, water purification, membrane separation, and plasma technology. Dr. El-Naas is a member of the Canadian Society of Chemical Engineers, a member of the American Institute of Chemical Engineers and a fellow of the International Congress of Chemistry and Environment. 